\title{
GENETIC BEHAVIOR OF YIELD, GRAIN QUALITY, STEM BORER AND STORAGE INSECT INFESTATION TRAITS FOR SOME RICE GENOTYPES AT DIFFERENT SOWING DATES. El-Malky, M.M. ${ }^{1}$ and H.M. El-Zun ${ }^{2}$ \\ 1. Rice Research and Training Center, Sakha, Kafr El-Sheikh, Field Crops Research Institute, Agricultural Research Center \\ 2. Dept. of Stored Product Pests, Plant Protection Res. Inst., Agricultural Research Center, Giza.
}

\begin{abstract}
The present investigation was carried out at Rice Research and Training Center and lab of Plant Protection Institute, Sakha, Kafr EL-Sheikh, Egypt, during 2011 and 2012 seasons. The objectives of this investigation is amid to study the genetic behavior of ten rice genotypes under three sowing dates (May $1^{\text {st }}$, May $15^{\text {th }}$ and May $30^{\text {th }}$ ), the effect of different sowing dates on grain quality characters, and on the infestation by stem borer and to evaluate the susceptibility of certain rice varieties against the infestation by Lesser grain borer, Rhizopertha dominica (F.). The tested genotypes were; Giza177, Giza 178, Sakha 101, Giza 182, GZ 9057-6-1-3-2, GZ 9577-4-1-1, GZ 9523-2-1-1-1, GZ 9461-4-2-3-1, Egyptian Yasmin, and SK2034 H1. Giza 178 cultivar produced maximum grain yield and it remained statistically at par with SK2034 genotype. Egyptian Yasmin gave minimum grain yield. Grain yield averaged across all the genotypes seems to be maximum at sowing date of $1^{\text {st }}$ May. However, the lowest yield was recorded in sowing date of $30^{\text {th }}$ May. Sowing dates significantly affected the milled rice \% in the first season only and highest milled rice $\%$ belonged to the second planting date in the first season. Highest milled rice \% were obtained for Giza 177 and GZ 9523-2-1-1-1; the lowest percentages were observed for GZ 9577-4-1-1 and Giza 178. For Stem borer (Chilo agamemnon Bles.), Giza 178, Sakha101, GZ 9577-4-1-1 and GZ 9461-4-2-3-1 were resistant (R) with 1.44, 0.83, 2.66 and $1.93 \mathrm{WH} \%$, respectively. While, five genotypes (Giza177, Giza182, GZ 9057, GZ 9577-4-1-1 and SK2034 H1) were moderately resistant (MR) with 4.18, $4.14,5.94,3.46$, and $5.36 \mathrm{WH} \%$, respectively. On the other hand, one genotype (Egyptian Yasmin) was moderately susceptible (MS) with $6.32 \mathrm{WH}$. The number of adult emergence of Rhizopertha dominica ranged from 1.08 insects (Sakha101) to 8.25 insects (GZ9577-4-1-1) (low susceptibility varieties to insect infestation). Also, the number of adult emergence ranged from 13.08 insects (Giza182) to 17.58 insects (Giza177) for moderate susceptibility varieties to insect infestation. Also, the number of adult emergence ranged from 21.08 insects (Egyptian Yasmin) to 22.58 insects (GZ 9057-6-1-3-2) which proved to be high susceptibility varieties to insect infestation. Clustering analysis for varieties, based on similarity of quantitative characters, produced two large distinct groups. The first one included five rice genotypes; Giza 178, Giza 182, GZ 9523-2-1-1-1, Egyptian Yasmin and SK2034 H1. These genotypes were Indica and Indica-Japonica types except Gz 9523-2-1-1-1 was Japonica type. While, the second group included Giza 177, Sakha 101, GZ 9057-6-1-3-2, GZ 9577 4-1-1 and GZ 9461-4-2-3-1, these genotypes were Japonica types and similar in duration and grain yield characters.

Keywords: rice, genetic behavior, yield, grain quality, Chilo agamemnon Bles.,
\end{abstract} Rhizopertha dominica (F.) 


\section{INTRODUCTION}

Rice (Oryza sativa L.) is the main food for about 3 billion people of the world and is the most common staple food of many countries, however $90 \%$ of the world's rice is produced and consumed in Asia, (Wassmann et al., 2009). In Egypt, rice is an important cash crop after cotton and average yield of rice is $10.4 \mathrm{t} / \mathrm{ha}$ (RRTC 2006). The potentiality of the varieties expressed differently due to planting in different dates (Ganajaxi et al. 2001 and Metwally et al. 2012). Also, optimum planting time is a major factor in rice cultivation and indirectly determines soil temperature and weather conditions (Ashrafuzzaman et al. 2009). Transplanting rice in the optimum period of time is critical to achieve high grain yield. However, optimum rice planting dates are regional and vary with location and genotypes (Sha and Linscombe, 2005; and Bruns and Abbas, 2006). Yoshida, (1981) reported that rice plants require a particular temperature for its phonological affairs such as panicle initiation; flowering, panicle exertions from flag leaf sheath and maturity and these are very much influenced by the planting dates during the season. Early planted photoperiod sensitive rice varieties passed lag vegetative phase which increased tallness as well as biomass that tended to lodge during grain filling stage (Akhter et al,. 2007). On the other hand, the delay sowing date is effected on the grain quality, flowering and yield per unit area of rice (Rashid et al., 2003).

The major components of rice grain quality its effected by environmental temperature during kernel development plays an integral role in causing the observed, unexplained fluctuations in rice grain quality (Cooper et al., 2006 and Zheng et al., 2008). Also, delay sowing date in rice increasing attacking by insect species and types specially the stem borer (Chilo Agamemnon Bles.) which is one of the most destructive and important rice pest in Egypt. In general, the occurrence and prevalence of an insect is affected by host plant availability, growth stage, population dynamics, sowing and transplanting dates (Chen et al. 2003 and Krell et al. 2005). Synthetic insecticides have been used since the $1950_{s}$ to control stored-products insects (Subramanyan and Hagstrum 1995). Pesticide residues in human and animal food, and environment is common, therefore alternative methods are needed to control stored-products insects. Since 1911, about 140 varieties of rice have been released in the United States of America (USA), with improved characteristics for agronomic production, field tolerance to insects and diseases, milling and cooking quality, and industrial cooking preferences (Moldenhauer et al., 2004). Rhizopertha dominica (F.) the lesser grain borer, is an important pest of most stored raw grains, including rough rice. The developing larva feeds inside grain kernels, and can cause weight loss and damage to the germ and endosperm in wheat as well as rice (Gundu Rao and Wilbur, 1957; Campbell and Sinha, 1976).

Genetic diversity can reduce vulnerability to stresses and it constitutes the raw material for plant breeders. Relative divergence measures among accessions can be based on quantitative morphological traits. Genetic relationships among individuals and populations can be measured by 
similarity of number of quantitative characters (Souza and Sorrells (1991), Dinghuhn and Asch (1999), Bahrman et al., (1999) and El-Malky (2004). A better knowledge of the genetic behavior of some aromatic varieties under different sowing dates would help to classify and identify varieties that would be grown successfully under late sowing date. The objectives of the present investigation were aimed to study the genetic behavior of ten rice genotypes under three sowing dates and the effect of different sowing dates on grain quality characters. 3) to evaluate the effect of different sowing dates on the infection by stem borer.4) to evaluate the susceptibility of certain rice varieties against the infestation by Lesser grain borer, Rhizopertha dominica (F.)

\section{MATERIALS AND METHODS}

Ten entries were selected to perform this study, and were classified into three categories, six entries as Japonica type, two entries as Indica type and two entries Indica-Japonica type as shown in (Table 1). These entries were inbreed lines except SK2034 the out breeding as hybrid variety and namely as Egyptian hybrid one. Three dates of sowing, i.e. May $1^{\text {st }}$, May $15^{\text {th }}$ and May30 $0^{\text {th }}$ were used in 2011 and 2012 seasons. At each sowing date, each entry were grown in $10 \mathrm{~m}^{2}$ in a randomized complete block design (RCBD) experiments with three replications. All the entries were evaluated for agronomic characters and stem borer at the experimental farm of Rice Research and Training Center (RRTC), Sakha, Kafr El-Sheikh, Egypt, during the rice growing seasons; 2011-2012. While, grain quality characters evaluated at Rice Research Technology Center, Alexandria. On the other hand, insects storage were studied at the lab. of Plant Protection Institute, Sakha, Kafr El-Sheikh.

Table 1 : Tested rice entries with parentage, origin and type.

\begin{tabular}{|l|c|c|c|c|}
\hline N0. & Entries & Parentage & Origin & Type \\
\hline 1 & Giza 177 & $\begin{array}{c}\text { Giza171/ Yomji } \\
\text { No.1//PiNo.4 }\end{array}$ & Egypt & Japonica \\
\hline 2 & Giza 178 & Giza175 / Milyang49 & Egypt & $\begin{array}{c}\text { Indica - } \\
\text { Japonica }\end{array}$ \\
\hline 3 & Sakha 101 & Giza176/ Milang79 & Egypt & Japonica \\
\hline 4 & Giza 182 & $\begin{array}{c}\text { Giza181/ IR39422-163- } \\
247-2-3 / / G i z a 181\end{array}$ & Egypt & Indica \\
\hline 5 & $\begin{array}{c}\text { GZ 9057-6-1-3- } \\
2(\text { Giza179) }\end{array}$ & Gz1368 / Gz6296 & Egypt & Japonica \\
\hline 6 & GZ 9577-4-1-1 & Gz6910 / Yunlong191 & Egypt & Japonica \\
\hline 7 & GZ 9523-2-1-1-1 & Gz6522 / Zhang Jia129 & Egypt & Japonica \\
\hline 8 & GZ 9461-4-2-3-1 & Doey2 Beyo / Gz6296 & Egypt & Japonica \\
\hline 9 & Egyptian Yasmin & (Jasmin85) IR841-67 & IRRI & Indica \\
\hline 10 & SK2034 H1 & IR69625 A/ Giza178 R & Egypt & $\begin{array}{c}\text { Indica - } \\
\text { Japonica }\end{array}$ \\
\hline
\end{tabular}

\section{Agronomic and grain quality characters:}

Duration (days), number of panicles/hill, number of filled grains/panicle, number of unfilled grains/panicle and grain yield (t/ha) were evaluated under different sowing dates and each entry was grown in $10 \mathrm{~m}^{2}$ in 
a randomized complete block design (RCBD) experiment with three replications. Grain quality characters i.e. brown rice percentage, milled rice percentage, head rice percentage and chalky \& green grain percentages.

\section{Insects tests:}

\section{a- Stem borers}

Stem borer damage was recorded as white head percentage at the maturity stage by counting the number of white head per 100 plants according to the standard evaluation system of Rice Research and Training Center (RRTC), Sakha, Egypt. Resistance $(R)=0-3 \%$, Moderately resistance $(M R)=3-6 \%$, Moderately susceptible $(M S)=6-9 \%$, Susceptible $(\mathrm{S})=9-12 \%$ and highly susceptible $(\mathrm{HS})=12 \%$ (Anonymous 2009 )

\section{b- Insects storage test:}

The original strains of all tested insects were obtained from the Department of Stored Product Pests, Plant protection Research Institute, Agricultural Research Center, Dokki, Egypt. Insect species were tested and their life cycles were identified according to the method mentioned by Badawy and Doraeham (1991).

\section{Lesser grain borer, Rhizopertha dominica (F.) (Fam. Bostrichidae):}

About 300 adults were added to a mixture of $150 \mathrm{gm}$ wheat kernels and $10 \mathrm{gm}$ wheat flour in a small jar and covered with muslin. Jars were maintained under conditions of $34 \pm 3^{\circ} \mathrm{C}$ and $70 \pm 1 \mathrm{R}$. H. Adults were left for two weeks for egg laying in the jars and were then removed. After two weeks, newly insects were collected by sieving and were used for experimentation.

For exposure the tested rice grains to insects, three $20 \mathrm{~g}$-grain samples were placed in small plastic jars $(6 \times 10 \mathrm{~cm}$ diameter). Twenty of newly emerging Rhizopertha dominica adults (0-24 hours old) were released in each jar and allowed to lay eggs. The jars were kept in the laboratory at constant conditions $\left(30 \pm 2^{\circ} \mathrm{C}, 70 \pm 5 \%\right.$ r.h.). After 20 days, the parents were removed. After emergence (23-25 days), No. of emerging adults, were recorded.

\section{Statistical analysis:}

A analysis of variance was carried out as a combined analysis for the four sowing dates in each season according to Gomez and Gomez (1984). Treatment means were compared by Duncan's Multiple Range Test (Duncan, 1955). All statistical analysis was performed using analysis of variance technique by means of "MSTATC" computer software package. The analysis was conducted using the Numerical Taxonomy and Multivariate Analysis system, Version 2.1 (NTSYSpc; Rolhf, 2000). The output was analyzed using an agglomerative hierarchical clustering method with complete linkage strategy. Firstly, the data was subjected to analysis to produce a matrix of dissimilarity values and the phenotypic distance between each pair of varieties was estimated as Euclidean distance. Secondly, cluster analysis was then conducted on the Euclidean distance matrix with un-weighed pairgroup method based on arithmetic average (UPGMA) to develop a dendogram.

\section{RESULTS AND DISCUSSION}

Plant growth duration is very important parameter as flowering behavior used as a criterion for identifying a rice genotype to be photoperiod 
sensitive. Duration was significant when assessed through the yardstick of statistics (Table 2). The longest duration mean (138 and 156 days) was noted for Egyptian Yasmin (156 days) followed by Sakha 101 which was followed by SK2034. The effect of different sowing dates on duration also remained significant. More number of days to maturity was taken by late sowing date in comparison with those in early sowing dates. The interaction between different genotypes and sowing dates remained statistically significant. It can be depicted from that plant growth duration behavior of all the rice genotypes that days to maturity decrease by delaying sowing. These results are in close agreement with that of Maiti and Sen (2003) who found that the growth duration exhibited an increasing trend of early planted crop and decreasing trend of late planted crop.

Table 2. Duration (days) of different rice genotypes as affected by sowing dates in 2011 and 2012 seasons.

\begin{tabular}{|c|c|c|c|c|c|c|c|c|}
\hline \multirow{3}{*}{$\begin{array}{l}\text { Genotypes } \\
\text { (G) }\end{array}$} & \multicolumn{8}{|c|}{ Sowing dates (S) } \\
\hline & \multicolumn{4}{|c|}{2011 season } & \multicolumn{4}{|c|}{2012 season } \\
\hline & $\begin{array}{l}\text { May } \\
1^{\text {st }}\end{array}$ & $\begin{array}{l}\text { May } \\
15^{\text {th }}\end{array}$ & $\begin{array}{l}\text { May } \\
30^{\text {th }}\end{array}$ & M & $\begin{array}{l}\text { May } \\
1^{\text {st }}\end{array}$ & $\begin{array}{l}\text { May } \\
15^{\text {th }}\end{array}$ & $\begin{array}{l}\text { May } \\
30^{\text {th }}\end{array}$ & M \\
\hline Giza 177 & 125 & 122 & 115 & 120.7 & 125 & 122 & 116 & 121 \\
\hline Giza 178 & 135 & 132 & 129 & 132.0 & 135 & 132 & 127 & 131 \\
\hline Sakha 101 & 141 & 138 & 135 & 138.0 & 141 & 138 & 139 & 139 \\
\hline Giza 182 & 127 & 124 & 121 & 124.0 & 127 & 124 & 118 & 123 \\
\hline GZ 9057-6-1-3-2 & 123 & 120 & 117 & 120.0 & 123 & 120 & 117 & 120 \\
\hline GZ 9577-4-1-1 & 127 & 123 & 120 & 123.3 & 127 & 123 & 119 & 123 \\
\hline GZ 9523-2-1-1-1 & 126 & 121 & 117 & 121.3 & 126 & 121 & 116 & 121 \\
\hline GZ 9461-4-2-3-1 & 125 & 121 & 118 & 121.3 & 125 & 121 & 115 & 120 \\
\hline Egyptian Yasmin & 153 & 156 & 159 & 156.0 & 153 & 155 & 160 & 156 \\
\hline SK2034 H1 & 136 & 133 & 130 & 133.0 & 136 & 133 & 129 & 133 \\
\hline Mean & 131 & 129 & 126. & & 131 & 128 & 125 & \\
\hline $\begin{array}{l}\text { L.S.D.-0.05 } \\
2011 \\
2012\end{array}$ & $\begin{array}{l}\text { Sowin } \\
1.6 \\
1.8\end{array}$ & & $\begin{array}{l}\text { Geno } \\
1.4 \\
1.3\end{array}$ & es $\mathbf{G}$ & $\begin{array}{l}S \times C \\
2.8 \\
2.8\end{array}$ & & & \\
\hline
\end{tabular}

The ability of various rice genotypes to produce productive tillers was affected significantly with different sowing dates. Maximum panicles were produced by most genotypes sown on $15^{\text {th }}$ May, whereas, the minimum number of panicles hill ${ }^{-1}$ was recorded in sowing date on $30^{\text {th }}$ May irrespective of various genotypes (Table 3 ). When results were averaged across dates for the comparison of various genotypes, it was noted that genotype SK2034 hybrid produced maximum tillers (23.11 and 23.00) in the two seasons respectively, which was followed by Giza 178 and GZ 9523-2-1-1-1. However, minimum panicles numbers (16.00 and 16.89) were produced by Egyptian Yasmin in the two seasons, respectively. The interaction between various genotypes and sowing dates indicated that SK2034 hybrid gave maximum number of fertile tillers hill $^{-1}$ when sown on $15^{\text {th }}$ May against minimum number of fertile tiller shown by GZ 9461-4-2-3-1 in $30^{\text {th }}$ May sowing date. These results are in consonance with the findings of Pandey et al. (2001) and Safdar et al. (2008). This was due to the fact that rice genotypes planted earlier had longer period for their vegetative growth compared to those sown later. Dawadi and Chaudhary (2013) indicated that 
significantly higher effective tiller per square meter in early sowing might be due to favorable environmental conditions which enabled the plant to improve its growth and development as compared to other sowing dates. It can be observed from (Table 4) that number of filled grains per panicle of different rice genotypes was affected significantly when assessed through the interaction of genotypes and sowing dates. SK2034 genotype showed maximum number of filled grains per panicle (206 and 200) an $15^{\text {th }}$ May and $1^{\text {st }}$ May sowing dates in the two seasons respectively, which was significantly different from all other treatment combinations. However, minimum number of filled grains per panicle was recorded in GZ 9461-4-2-3-1 genotype (63.7 and 78.7) when sown on $30^{\text {th }}$ May in the two seasons, respectively.

Table 3.Number of panicles per hill of different rice genotypes as affected by sowing dates in 2011 and 2012 seasons.

\begin{tabular}{|c|c|c|c|c|c|c|c|c|}
\hline \multirow{3}{*}{$\begin{array}{l}\text { Genotypes } \\
\text { (G) }\end{array}$} & \multicolumn{8}{|c|}{ Sowing dates (S) } \\
\hline & \multicolumn{4}{|c|}{2011 season } & \multicolumn{4}{|c|}{2012 season } \\
\hline & $\underset{1^{\text {st }}}{\text { May }}$ & $\begin{array}{l}\text { May } \\
15^{\text {th }}\end{array}$ & $\begin{array}{l}\text { May } \\
30^{\text {th }}\end{array}$ & M & $\underset{1^{\text {st }}}{\text { May }}$ & $\begin{array}{l}\text { May } \\
15^{\text {th }}\end{array}$ & $\begin{array}{l}\text { May } \\
30^{\text {th }}\end{array}$ & M \\
\hline Giza 177 & 18.3 & 20.3 & 16.0 & 18.2 & 19.6 & 19.6 & 18.0 & 19.1 \\
\hline Giza 178 & 20.0 & 24.3 & 18.6 & 21.0 & 21.6 & 21.3 & 19.3 & 20.7 \\
\hline Sakha 101 & 17.6 & 19.6 & 14.3 & 17.2 & 18.6 & 19.3 & 15.6 & 17.8 \\
\hline Giza 182 & 18.0 & 16.6 & 18.6 & 17.7 & 18.3 & 17.6 & 25.3 & 20.4 \\
\hline GZ 9057-6-1-3-2 & 18.6 & 19.3 & 18.0 & 18.6 & 19.0 & 18.0 & 19.6 & 18.8 \\
\hline GZ 9577-4-1-1 & 19.0 & 18.6 & 20.6 & 19.4 & 22.6 & 19.3 & 21.3 & 21.1 \\
\hline GZ 9523-2-1-1-1 & 18.6 & 20.6 & 21.0 & 20.1 & 16.6 & 18.3 & 18.6 & 17.8 \\
\hline GZ 9461-4-2-3-1 & 17.0 & 18.0 & 16.0 & 17.0 & 20.0 & 20.0 & 15.6 & 18.5 \\
\hline Egyptian Yasmin & 17.0 & 17.3 & 13.6 & 16.0 & 17.3 & 17.3 & 16.0 & 16.8 \\
\hline SK2034 H1 & 23.0 & 26.0 & 20.3 & 23.1 & 23.3 & 26.0 & 19.6 & 23.0 \\
\hline Mean & 18.7 & 20.1 & 17.7 & 18.8 & 19.7 & 19.7 & 18.9 & 19.4 \\
\hline $\begin{array}{l}\text { L.S.D.0.05 } \\
2011 \\
2012\end{array}$ & $\begin{array}{l}\text { Sowing } \\
1.11 \\
\text { N.S }\end{array}$ & & $\begin{array}{l}\text { Genot } \\
1.7 \\
1.4\end{array}$ & & $\begin{array}{l}S \times C \\
3.0 \\
2.4\end{array}$ & & & \\
\hline
\end{tabular}

Means of genotypes across three sowing dates showed that genotype SK2034 produced maximum number of filled grains per panicle (182.4 and 174.8) in the two seasons, respectively, which was significantly different from all other genotypes. However minimum number of filled grains per panicle (94.7 and 108.4) were recorded in rice genotype GZ 9577-4-1-1 in the two seasons, respectively. In the same way, average number of filled grains per panicle across 10 rice genotypes indicated that rice sowed on $1^{\text {st }}$ May produced maximum number of filled grains per panicle of 151.2 and 153.1 in the two seasons respectively, which remained statistically at par with that sowed in $15^{\text {th }}$ May. Nazir (1994) reported that earlier transplanting in rice causes lower number of grains panicle ${ }^{-1}$ due to grain sterility because of high temperature at the time of grain filling and maturation. Transplanting at its optimum time reduces grain sterility. Sha X. and Linscombe (2005) and Dawadi and Chaudhary (2013) reported that more number of filled grains per panicle was visualized in the early seeding and declined gradually in the successive seeding dates. 
Table 4. Number of filled grains per panicle of different rice genotypes as affected by sowing dates in 2011 and 2012 seasons.

\begin{tabular}{|c|c|c|c|c|c|c|c|c|}
\hline \multirow{3}{*}{$\begin{array}{l}\text { Genotypes } \\
\text { (G) }\end{array}$} & \multicolumn{8}{|c|}{ Sowing dates (S) } \\
\hline & \multicolumn{4}{|c|}{2011 season } & \multicolumn{4}{|c|}{2012 season } \\
\hline & May $1^{\text {st }}$ & May $15^{\text {th }}$ & May $30^{\text {th }}$ & $\mathbf{M}$ & May $1^{\text {st }}$ & May $15^{\mathrm{th}}$ & May $30^{\text {th }}$ & $\mathbf{M}$ \\
\hline Giza 177 & 145.7 & 118.3 & 120.3 & 128.1 & 145.7 & 123.3 & 121.0 & 130.0 \\
\hline Giza 178 & 173.0 & 161.7 & 143.0 & 159.2 & 183.0 & 186.7 & 145.0 & 171.6 \\
\hline Sakha 101 & 152.3 & 104.0 & 118.3 & 124.9 & 157.7 & 131.3 & 120.7 & 136.6 \\
\hline Giza 182 & 134.0 & 150.3 & 113.7 & 132.7 & 150.0 & 163.3 & 106.7 & 140.0 \\
\hline GZ 9057-6-1-3-2 & 138.3 & 123.3 & 91.0 & 117.6 & 116.3 & 115.3 & 104.7 & 112.1 \\
\hline GZ 9577-4-1-1 & 114.3 & 90.3 & 79.3 & 94.7 & 123.7 & 107.0 & 94.7 & 108.4 \\
\hline GZ 9523-2-1-1-1 & 176.3 & 178.0 & 106.7 & 153.7 & 164.3 & 175.7 & 124.7 & 154.9 \\
\hline GZ 9461-4-2-3-1 & 142.0 & 112.0 & 63.7 & 105.9 & 133.7 & 113.3 & 78.7 & 108.6 \\
\hline Egyptian Yasmin & 139.7 & 164.7 & 157.3 & 153.9 & 156.7 & 193.0 & 146.7 & 165.4 \\
\hline SK2034 H1 & 196.7 & 206.0 & 144.7 & 182.4 & 200.0 & 163.7 & 160.7 & 174.8 \\
\hline Mean & 151.2 & 140.9 & 113.8 & 135.3 & 153.1 & 147.3 & 120.3 & 140.2 \\
\hline $\begin{array}{l}\text { L.S.D. } 0.05 \\
2011 \\
2012\end{array}$ & $\begin{array}{l}\text { Sowing } \\
10.5 \\
13.1\end{array}$ & & $\begin{array}{l}\text { Geno } \\
12.7 \\
11.9\end{array}$ & es $G$ & $\begin{array}{l}\mathrm{S} \times \mathrm{G} \\
22.3 \\
21.8\end{array}$ & & & \\
\hline
\end{tabular}

Results presented in Table 5 indicated that difference among various genotypes for unfilled grains per panicle was significant statistically irrespective of transplanting dates. Egyptian Yasmin produced unfilled grains per panicle with maximum values of 20.67 and 25.44 in the two seasons respectively, in contrast to GZ 9577-4-1-1 which produced minimum values at 5.11 and 6.44 in the two seasons respectively. Similarly, means of transplanting dates across genotypes expressed that maximum values for unfilled grains per panicle $(21.58 \mathrm{~g})$ were noted for genotypes sowed on $1^{\text {st }}$ May while genotypes transplanted on $30^{\text {th }}$ May. Interaction between various genotypes and sowing dates, as depicted in Table 5, also remained significant when examined through statistics. Egyptian Yasmin produced maximum values of unfilled grains per panicle (31.67) in $1^{\text {st }}$ May sowing date in the first season and (38.00) in $15^{\text {th }}$ May in the second season, in contrast with GZ 9057-6-1-3-2 which gave minimum unfilled grains per panicle valued at 1.67 and 4.33 in $30^{\text {th }}$ May in the two seasons, respectively.

Table 5. Number unfilled grains per panicle of different rice genotypes as affected by sowing dates in 2011 and 2012 seasons.

\begin{tabular}{|c|c|c|c|c|c|c|c|c|}
\hline \multirow{3}{*}{$\begin{array}{l}\text { Genotypes } \\
\text { (G) }\end{array}$} & \multicolumn{8}{|c|}{ Sowing dates (S) } \\
\hline & \multicolumn{4}{|c|}{2011 season } & \multicolumn{4}{|c|}{2012 season } \\
\hline & May $1^{\text {st }}$ & May $15^{\text {th }}$ & May $30^{\mathrm{th}}$ & $\mathbf{M}$ & May $1^{\text {st }}$ & May $15^{\text {th }}$ & May $30^{\text {th }}$ & $\mathbf{M}$ \\
\hline Giza 177 & 16.6 & 4.6 & 9.0 & 10.1 & 9.0 & 4.0 & 7.0 & 6.6 \\
\hline Giza 178 & 7.0 & 12.0 & 3.0 & 7.3 & 8.6 & 9.0 & 3.3 & 7.0 \\
\hline Sakha 101 & 16.0 & 11.6 & 5.0 & 10.8 & 26.6 & 12.3 & 6.3 & 15.1 \\
\hline Giza 182 & 29.3 & 11.0 & 10.3 & 16.8 & 18.6 & 10.3 & 6.3 & 11.7 \\
\hline GZ 9057-6-1-3-2 & 10.6 & 11.3 & 1.6 & 7.8 & 23.0 & 15.0 & 4.3 & 14.1 \\
\hline GZ 9577-4-1-1 & 8.0 & 3.3 & 4.0 & 5.1 & 10.3 & 4.0 & 5.0 & 6.4 \\
\hline GZ 9523-2-1-1-1 & 19.3 & 14.0 & 5.6 & 13.0 & 14.6 & 9.3 & 6.6 & 10.2 \\
\hline GZ 9461-4-2-3-1 & 15.0 & 21.0 & 10.0 & 15.3 & 15.3 & 19.0 & 6.3 & 13.5 \\
\hline Egyptian Yasmin & 31.6 & 17.6 & 12.6 & 20.6 & 32.0 & 38.0 & 6.3 & 25.4 \\
\hline SK2034 H1 & 8.3 & 13.3 & 13.3 & 11.6 & 9.3 & 13.3 & 16.0 & 12.8 \\
\hline Mean & 16.20 & 12.0 & 7.4 & & 16.7 & 13.4 & 6.7 & \\
\hline $\begin{array}{l}\text { L.S.D.0.05 } \\
2011 \\
2012\end{array}$ & \multicolumn{2}{|c|}{$\begin{array}{l}\text { Sowing S } \\
2.8 \\
3.2\end{array}$} & $\begin{array}{l}\text { Genot } \\
2.8 \\
5.0\end{array}$ & & \multicolumn{2}{|c|}{$\begin{array}{l}\text { S x G } \\
9.4 \\
8.6\end{array}$} & & \\
\hline
\end{tabular}

The most important parameter and ultimate task of farming is grain yield which was affected significantly with various genotypes as well as sowing dates. It can be observed from results presented in Table 6 that Giza 
178 produced maximum grain yield of 9.040 and $8.99 \mathrm{t} \mathrm{ha}^{-1}$ and it remained statistically at par with SK2034 genotype with 8.87 and $8.81 \mathrm{t} \mathrm{ha}^{-1}$ grain yield in the two seasons, respectively. Egyptian Yasmin gave minimum grain yield $\left(6.18\right.$ and $\left.6.12 \mathrm{t} \mathrm{ha}^{-1}\right)$ in the two seasons, respectively. Grain yield averaged across all the genotypes seems to be maximum $\left(9.09\right.$ and $\left.8.93 \mathrm{t} \mathrm{ha}^{-1}\right)$ in sowing date on $1^{\text {st }}$ May. However, the lowest yield (5.31 and $5.18 \mathrm{t} \mathrm{ha}^{-1}$ ) was recorded in sowing date on $30^{\text {th }}$ May. Interaction between sowing dates and genotypes showed that rice Giza 178 gave highest paddy yield of 10.85 and $10.71 \mathrm{t} \mathrm{ha} \mathrm{C}^{-1}$ in $1^{\text {st }}$ May sowing date in the two seasons, respectively, which is statistically similar with that obtained by SK2034. The lowest grain yield (2.93 and $3.01 \mathrm{t}$ ha-1) in the two seasons, respectively were recorded by Egyptian Yasmin when sowing on $30^{\text {th }}$ May. Similar results were reported by Akram et al., (2007) who found higher paddy yield in earlier transplanting dates compared with the late transplanting. The findings of Munda et al., (1994), and Safdar et al., (2008). were also in the same direction. Dawadi and Chaudhary (2013) indicated the higher yield in case of early sowing was attributed to increased cumulative mean value of temperature and sunshine hour due to early sowing, more number of productive tillers, more number of grains per panicle, and higher test weight.

Table 6. Grain yield ( $\left.\mathrm{t} \mathrm{ha}{ }^{-1}\right)$ of different rice genotypes as affected by sowing dates in 2011 and 2012 seasons.

\begin{tabular}{|c|c|c|c|c|c|c|c|c|}
\hline \multirow{3}{*}{$\begin{array}{l}\text { Genotypes } \\
\text { (G) }\end{array}$} & \multicolumn{8}{|c|}{ Sowing dates (S) } \\
\hline & \multicolumn{4}{|c|}{2011 season } & \multicolumn{4}{|c|}{2012 season } \\
\hline & May $1^{\text {st }}$ & $\begin{array}{l}\text { May } \\
15^{\text {th }}\end{array}$ & $\begin{array}{l}\text { May } \\
30^{\text {th }}\end{array}$ & $\mathbf{M}$ & May $1^{\text {st }}$ & $\begin{array}{l}\text { May } \\
15^{\text {th }}\end{array}$ & $\begin{array}{l}\text { May } \\
30^{\text {th }}\end{array}$ & M \\
\hline Giza 177 & 8.1 & 7.9 & 5.3 & 7.1 & & 7.8 & 4.7 & 6.8 \\
\hline Giza 178 & 10.8 & 9.8 & 6.4 & 9.0 & 7.9 & 9.7 & 6.5 & 8.9 \\
\hline Sakha 101 & 8.7 & 8.5 & 5.2 & 7.5 & $\begin{array}{ll}10.1 \\
0.2\end{array}$ & 8.4 & 4.6 & 7.1 \\
\hline Giza 182 & 9.2 & 8.2 & 5.5 & 7.6 & 0.3 & 8.1 & 5.6 & 7.6 \\
\hline GZ 9057-6-1-3-2 & 9.8 & 9.4 & 6.5 & 8.6 & $\begin{array}{ll}9.1 & 9.7 \\
& 3\end{array}$ & 9.3 & 6.6 & 8.5 \\
\hline GZ 9577-4-1-1 & 8.4 & 7.2 & 5.1 & 6.9 & 8.3 & 7.1 & 4.5 & 6.7 \\
\hline GZ 9523-2-1-1-1 & 8.7 & 7.5 & 4.8 & 7.0 & 8.5 & 7.4 & 4.9 & 6.9 \\
\hline GZ 9461-4-2-3-1 & 8.2 & 7.0 & 4.3 & 6.5 & 8.1 & 6.9 & 4.4 & 6.5 \\
\hline Egyptian Yasmin & 8.1 & 7.4 & 2.9 & 6.1 & 7.9 & 7.3 & 3.0 & 6.1 \\
\hline SK2034 H1 & 10.5 & 9.3 & 6.7 & 8.8 & 10.4 & 9.2 & 6.7 & 8.8 \\
\hline Mean & 9.1 & 8.2 & 5.3 & & 8.9 & 8.1 & 5.1 & \\
\hline $\begin{array}{l}\text { L.S.D.0.05 } \\
2011 \\
2012\end{array}$ & \multicolumn{2}{|c|}{$\begin{array}{l}\text { Sowing S } \\
0.33 \\
0.32\end{array}$} & \multicolumn{2}{|c|}{$\begin{array}{l}\text { Genotypes G } \\
0.41 \\
0.37\end{array}$} & \multicolumn{2}{|l|}{$\begin{array}{l}\times G \times \\
0.72 \\
0.65\end{array}$} & & \\
\hline
\end{tabular}

These differences among the sowing dates were probably related to differences in weather conditions (air temperature Fig. 1). The differences in average air temperature were markedly pronounced among sowing dates at early growth stage from 1 to 60 days after sowing (DAS) and at the late growth stage from 60 DAS to maturity. Where, air temperature tended to be lower at the first period (up to 60 DAS) in the first sowing date than the others. The inverse was true in the second period (from 75 DAS to maturity) in both seasons. Suitable solar radiation together with lower soil temperature in the first and second sowing dates might have increased photosynthesis and decrease respiration, thereby increased the amount of assimilates, available for growth which was reflected in more dry matter accumulation (more tillers and leaf area per unit area). 

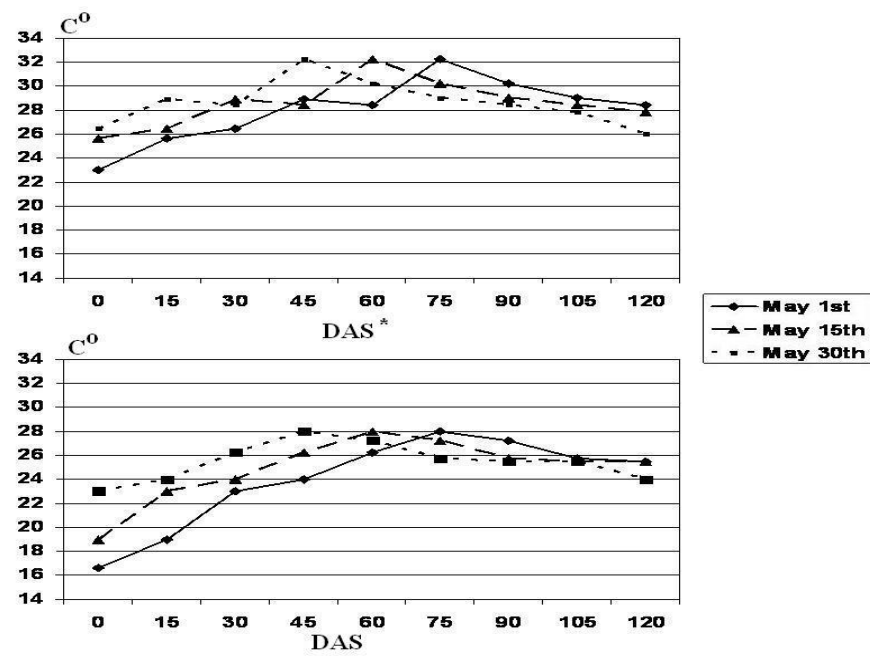
\begin{tabular}{l}
$-1-$ May 15th \\
-- - May 30th \\
\hline
\end{tabular}

Fig 1. Mean temperature at the three sowing dates in 2011 and 2012 seasons.

* Number of days after sowing (DAS).

The influence of sowing date on brown rice percentage was not significant but the difference among genotypes and also the interaction effect of sowing date and genotype were significant in terms of brown rice percentage (Table 7). The lowest brown rice percentage was observed in Giza 178 while the highest percentage was produced by GZ 9057-6-1-3-2 genotype. The interaction effects of sowing date and genotype were significant on brown rice percentage. The highest percentage belonged to $G Z$ 9057-6-1-3-2 genotype in the first sowing date with an average of 81.90 and 82.50 in the two seasons respectively. Brown rice percentage analysis indicates this percentage is completely influenced by genetic background of the genotypes because each genotype exhibited its highest fertility percentage under the optimum sowing date.

Table 7. Brown rice \% of different rice genotypes as affected by sowing dates in 2011 and 2012 seasons.

\begin{tabular}{|c|c|c|c|c|c|c|c|c|}
\hline \multirow{3}{*}{$\begin{array}{c}\text { Genotypes } \\
\text { (G) }\end{array}$} & \multicolumn{8}{|c|}{ Sowing dates (S) } \\
\hline & \multicolumn{4}{|c|}{2011 season } & \multicolumn{4}{|c|}{2012 season } \\
\hline & May $1^{\text {st }}$ & $\begin{array}{l}\text { May } \\
15^{\text {th }}\end{array}$ & $\begin{array}{c}\text { May } \\
30^{\text {th }}\end{array}$ & M & May $1^{\text {st }}$ & $\begin{array}{l}\text { May } \\
15^{\text {th }}\end{array}$ & $\begin{array}{l}\text { May } \\
30^{\text {th }}\end{array}$ & M \\
\hline Giza 177 & 79.2 & 81.4 & 78.8 & 79.8 & 79.8 & 80.9 & 79.4 & 80.0 \\
\hline Giza 178 & 78.6 & 79.1 & 78.4 & 78.7 & 79.2 & 78.6 & 79.0 & 78.9 \\
\hline Sakha 101 & 80.3 & 79.4 & 79.9 & 79.8 & 80.9 & 78.9 & 80.5 & 80.1 \\
\hline Giza 182 & 80.7 & 81.4 & 78.4 & 80.1 & 81.3 & 80.9 & 79.0 & 80.4 \\
\hline GZ 9057-6-1-3-2 & 81.9 & 80.9 & 80.1 & 80.9 & 82.5 & 80.4 & 80.7 & 81.2 \\
\hline GZ 9577-4-1-1 & 78.8 & 80.5 & 79.1 & 79.4 & 79.4 & 80.0 & 79.7 & 79.7 \\
\hline GZ 9523-2-1-1-1 & 80.9 & 80.2 & 80.3 & 80.4 & 81.5 & 79.7 & 80.9 & 80.7 \\
\hline GZ 9461-4-2-3-1 & 79.8 & 80.2 & 81.2 & 80.4 & 80.4 & 79.7 & 81.8 & 80.6 \\
\hline Egyptian Yasmin & 81.2 & 79.5 & 80.0 & 80.2 & 81.8 & 79.0 & 80.6 & 80.5 \\
\hline SK2034 H1 & 76.7 & 80.7 & 79.1 & 78.8 & 77.3 & 80.2 & 79.7 & 79.1 \\
\hline Mean & 79.8 & 80.3 & 79.5 & 79.8 & 80.4 & 79.8 & 80.1 & 80.1 \\
\hline $\begin{array}{l}\text { L.S.D. }_{0.05} \\
2011 \\
2012\end{array}$ & $\begin{array}{l}\text { Sowing S } \\
\text { N.S } \\
\text { N.S }\end{array}$ & & $\begin{array}{l}\text { Genot } \\
0.74 \\
0.84\end{array}$ & es $\mathbf{G}$ & $\begin{array}{l}S \times G \\
1.54 \\
1.55\end{array}$ & & & \\
\hline
\end{tabular}


Planting date significantly affected milled rice \% in the first season only (Table 8). Highest milled rice \% belonged to the second planting date in the first season. There was a significant difference among genotypes in terms of milled rice \%. The highest milled rice \% were obtained from Giza 177 and GZ 9523-2-1-1-1; the lowest percentages were observed for GZ 9577-4-1-1 and Giza 178 cultivar. This disparity was caused by the difference between genotypes in terms of the starch accumulation ability.

The interaction effects of planting dates and genotypes were significant on milled rice \% (Table 8). Highest milled rice \% were observed in the second planting date for Giza 177 (70.3 and 72.6\%in 2011 and 2012 resp.)on the other hand, GZ 9577-4-1-1genotype gave the lowest percentage in the first planting date (67.0 and $67.5 \%$ resp.). Most genotypes exhibited their largest milled rice \% in the second planting date. This may be due to that excessive heat during the pollination period and grain filling stage caused disorder in grain formation and grain weight which reduced the milled \%.

Table 8. Milled rice \% of different rice genotypes as affected by sowing dates in 2011 and 2012 seasons.

\begin{tabular}{|c|c|c|c|c|c|c|c|c|}
\hline \multirow{3}{*}{$\begin{array}{l}\text { Genotypes } \\
\text { (G) }\end{array}$} & \multicolumn{8}{|c|}{ Sowing dates (S) } \\
\hline & \multicolumn{4}{|c|}{2011 season } & \multicolumn{4}{|c|}{2012 season } \\
\hline & May $1^{\text {st }}$ & $\begin{array}{l}\text { May } \\
15^{\text {th }}\end{array}$ & $\begin{array}{c}\text { May } \\
30^{\text {th }}\end{array}$ & M & May $1^{\text {st }}$ & $\begin{array}{l}\text { May } \\
15^{\text {th }}\end{array}$ & \begin{tabular}{|c|} 
May \\
$30^{\text {th }}$
\end{tabular} & M \\
\hline Giza 177 & 69.00 & 73.30 & 68.20 & 70.17 & 69.55 & 72.65 & 68.90 & 70.37 \\
\hline Giza 178 & 67.80 & 68.10 & 68.40 & 68.10 & 68.35 & 67.45 & 69.10 & 68.30 \\
\hline Sakha 101 & 70.30 & 69.00 & 69.30 & 69.53 & 70.85 & 68.35 & 70.00 & 69.73 \\
\hline Giza 182 & 69.50 & 71.10 & 67.80 & 69.47 & 70.05 & 70.45 & 68.50 & 69.67 \\
\hline GZ 9057-6-1-3-2 & 70.30 & 69.80 & 69.80 & 69.97 & 70.85 & 69.15 & 70.50 & 70.17 \\
\hline GZ 9577-4-1-1 & 67.00 & 69.00 & 68.20 & 68.07 & 67.55 & 68.35 & 68.90 & 68.27 \\
\hline GZ 9523-2-1-1-1 & 69.90 & 70.30 & 69.90 & 70.03 & 70.45 & 69.65 & 70.60 & 70.23 \\
\hline GZ 9461-4-2-3-1 & 68.10 & 70.60 & 69.30 & 69.33 & 68.65 & 69.95 & 70.00 & 69.53 \\
\hline Egyptian Yasmin & 70.30 & 68.60 & 69.50 & 69.47 & 70.85 & 67.95 & 70.20 & 69.67 \\
\hline SK2034 H1 & 67.80 & 70.40 & 67.70 & 68.63 & 68.35 & 69.75 & 68.40 & 68.83 \\
\hline Mean & 69.00 & 70.02 & 68.81 & & 69.55 & 69.37 & 69.51 & 69.48 \\
\hline $\begin{array}{l}\text { L.S.D.0.05 } \\
2011 \\
2012\end{array}$ & \multicolumn{2}{|c|}{$\begin{array}{l}\text { Sowing S } \\
0.79 \\
\text { N.S. }\end{array}$} & \multicolumn{2}{|c|}{$\begin{array}{l}\text { Genotypes } \mathbf{G} \\
0.92 \\
1.05\end{array}$} & $\begin{array}{l}S \times G \\
1.29 \\
195\end{array}$ & & & \\
\hline
\end{tabular}

Sowing date significantly influenced broken rice percentage in the two seasons (Table 9). Rice plants sown on the early and late dates and recorded higher broken rice percentage than those sown on the $15^{\text {th }}$ May in the two seasons. Rice genotypes revealed a significant difference on broken rice percentage in the two seasons. Grains of Giza 182 and GZ 9057-6-1-3-2 genotype recorded highest broken rice percentage in the two seasons. However, Egyptian Yasmin recorded the lowest one. The interaction between sowing dates and rice genotypes had a significant effect on broken rice percentage in the two season (Table 9). Giza 182 cultivar sown on $1^{\text {st }}$ May recorded the highest broken rice percentage in the two seasons while Egyptian Yasmin produced the lowest percentage when sowed on the first sowing dates. 
Table 9. Broken rice \% of different rice genotypes as affected by sowing dates in 2011 and 2012 seasons.

\begin{tabular}{|c|c|c|c|c|c|c|c|c|}
\hline \multirow{3}{*}{$\begin{array}{c}\text { Genotypes } \\
\text { (G) }\end{array}$} & \multicolumn{8}{|c|}{ Sowing dates (S) } \\
\hline & \multicolumn{4}{|c|}{2011 season } & \multicolumn{4}{|c|}{2012 season } \\
\hline & May $1^{\text {st }}$ & $\begin{array}{l}\text { May } \\
15^{\text {th }}\end{array}$ & $\begin{array}{c}\text { May } \\
30^{\text {th }}\end{array}$ & M & May $1^{\text {st }}$ & $\begin{array}{l}\text { May } \\
15^{\text {th }}\end{array}$ & $\begin{array}{c}\text { May } \\
30^{\text {th }}\end{array}$ & $\mathbf{M}$ \\
\hline Giza 177 & 7.90 & 5.75 & 9.40 & 7.68 & 8.30 & 6.25 & 10.00 & 8.18 \\
\hline Giza 178 & 7.10 & 5.05 & 7.40 & 6.52 & 7.50 & 5.55 & 8.00 & 7.02 \\
\hline Sakha 101 & 9.10 & 8.05 & 9.50 & 8.88 & 9.50 & 8.55 & 10.10 & 9.38 \\
\hline Giza 182 & 14.10 & 8.65 & 7.10 & 9.95 & 14.50 & 9.15 & 7.70 & 10.45 \\
\hline GZ 9057-6-1-3-2 & 9.60 & 10.25 & 9.00 & 9.62 & 10.00 & 10.75 & 9.60 & 10.12 \\
\hline GZ 9577-4-1-1 & 11.60 & 8.05 & 7.80 & 9.15 & 12.00 & 8.55 & 8.40 & 9.65 \\
\hline GZ 9523-2-1-1-1 & 8.30 & 2.85 & 9.30 & 6.82 & 8.70 & 3.35 & 9.90 & 7.32 \\
\hline GZ 9461-4-2-3-1 & 7.10 & 3.65 & 10.80 & 7.18 & 7.50 & 4.15 & 11.40 & 7.68 \\
\hline Egyptian Yasmin & 3.50 & 7.05 & 5.90 & 5.48 & 3.90 & 7.55 & 6.50 & 5.98 \\
\hline SK2034 H1 & 5.20 & 9.05 & 5.50 & 6.58 & 5.60 & 9.55 & 6.10 & 7.08 \\
\hline Mean & 8.35 & 6.84 & 8.17 & & 8.75 & 7.34 & 8.77 & 8.29 \\
\hline $\begin{array}{l}\text { L.S.D.0.05 } \\
2011 \\
2012\end{array}$ & \multicolumn{2}{|l|}{$\begin{array}{l}\text { Sowing S } \\
0.11 \\
0.13\end{array}$} & \multicolumn{2}{|c|}{$\begin{array}{l}\text { Genotypes G } \\
0.13 \\
0.16\end{array}$} & $\begin{array}{l}S \times G \\
0.22 \\
0-31\end{array}$ & & & \\
\hline
\end{tabular}

Sowing dates significantly influenced chalky and green grain percentage in the two seasons. Rice plants sown on $15^{\text {th }}$ May recorded higher chalky and green grain percentage than those sown on the early and late sowing dates in the two seasons. Rice genotypes revealed a significant difference on chalky and green grain in the two seasons. Giza 182, Sakha 101 and SK2034 H1cultivar exceeded the other genotypes in percentage in the two seasons. The interaction between sowing date and rice genotypes had a significant effect on chalky and green grain percentage in the two seasons (Table 10). GZ 9461-4-2-3-1 genotype sown on $1^{\text {st }}$ May recorded highest chalky and green grain in the two seasons.

Table 10. Chalky and green grain \% of different rice genotypes as affected by sowing dates in 2011 and 2012 seasons.

\begin{tabular}{|c|c|c|c|c|c|c|c|c|}
\hline \multirow{3}{*}{$\begin{array}{c}\text { Genotypes } \\
\text { (G) }\end{array}$} & \multicolumn{8}{|c|}{ Sowing dates (S) } \\
\hline & \multicolumn{4}{|c|}{2011 season } & \multicolumn{4}{|c|}{2012 season } \\
\hline & May $1^{\text {st }}$ & May $15^{\text {th }}$ & May $30^{\text {th }}$ & $\mathbf{M}$ & May $1^{\text {st }}$ & May $15^{\text {th }}$ & May $30^{\text {th }}$ & M \\
\hline Giza 177 & 1.10 & 1.55 & 1.35 & 1.33 & 1.30 & 1.85 & 1.65 & 1.60 \\
\hline Giza 178 & 1.40 & 1.15 & 1.65 & 1.40 & 1.60 & 1.45 & 1.95 & 1.67 \\
\hline Sakha 101 & 1.80 & 1.95 & 1.95 & 1.90 & 2.00 & 2.25 & 2.25 & 2.17 \\
\hline Giza 182 & 2.00 & 1.95 & 1.85 & 1.93 & 2.20 & 2.25 & 2.15 & 2.20 \\
\hline GZ 9057-6-1-3-2 & 1.60 & 1.65 & 2.05 & 1.77 & 1.80 & 1.95 & 2.35 & 2.03 \\
\hline GZ 9577-4-1-1 & 0.80 & 1.95 & 1.65 & 1.47 & 1.00 & 2.25 & 1.95 & 1.73 \\
\hline GZ 9523-2-1-1-1 & 0.60 & 1.35 & 1.05 & 1.00 & 0.80 & 1.65 & 1.35 & 1.27 \\
\hline GZ 9461-4-2-3-1 & 2.20 & 1.45 & 1.15 & 1.60 & 2.40 & 1.75 & 1.45 & 1.87 \\
\hline Egyptian Yasmin & 1.50 & 1.05 & 0.95 & 1.17 & 1.70 & 1.35 & 1.25 & 1.43 \\
\hline SK2034 H1 & 1.80 & 2.35 & 1.55 & 1.90 & 2.00 & 2.65 & 1.85 & 2.17 \\
\hline Mean & 1.48 & 1.64 & 1.52 & & 1.68 & 1.94 & 1.82 & \\
\hline $\begin{array}{l}\text { L.S.D.0.05 } \\
2011 \\
2012\end{array}$ & $\begin{array}{l}\text { owing } 5 \\
.05 \\
.06\end{array}$ & & $\begin{array}{l}\text { Genot } \\
0.06 \\
0.06\end{array}$ & & $\begin{array}{l}\mathrm{S} \times \mathrm{G} \\
0.65 \\
0.66\end{array}$ & & & \\
\hline
\end{tabular}

Evaluation of rice varieties to insects test:

Stem borer (Chilo agamemnon Bles.)

For white head \% (stem borer, Chilo agamemnon Bles.) in season 2011, results presented in Table 11 revealed that genotypes (Giza 178, Sakha101, GZ 9577-4-1-1 and GZ 9461-4-2-3-1) were resistant (R) with 1.44, 
$0.83,2.66$ and $1.93 \mathrm{WH} \%$, respectively. These genotypes were belonged to true Japonica types except Giza 178 cultivar that was Indica-Japonica. While, five genotypes (Giza177, Giza182, GZ 9057, GZ 9577-4-1-1 and SK2034 H1) were moderately resistant (MR) with $4.18,4.14,5.94,3.46$, and $5.36 \mathrm{WH} \%$, respectively. On the other hand, one genotype (Egyptian Yasmin) was moderately susceptible (MS) with $6.32 \mathrm{WH} \%$. these genotypes including one Indica type (Giza182), two Indica-Japonica (GZ 9057-6-1-3-2 and SK2034 $\mathrm{H} 1$ ) and two true Japonica types (Giza177 and GZ 9523-2-1-1-1). It was found that the japonica types were more resistant to stem borer. This was previously conformed by Pathak (1967), Tantawi (1985) and Bleih et al (1991) who concluded that rice verities belonging to Indica type are more susceptible to stem borer than those belonging to japonica or Indica $x$ Japonica types. Djamin and Pathak (1967) concluded that japonica rices have more silica content than Indica rices. The high level of silica seemed to interface with feeding and boring of the rice stem borer larvae and could cause defacing of the mandibles. In 2012 season, the rice stem borer infestation was the highest with genotypes GZ 9577-4-1-1 and GZ 9461-4-23-1 comparing with the data in 2011 rice seasons. This could by attributed that inset populations, in general, fluctuated from one season to another, and may appear in outbreak in some seasons. This could by attributed to imbalance in the ecosystem due to distraction of nature entries, for example as a result to high applications of pesticides. These results are in agreement with those of Hammoud et al (2012) and El-Malky et al (2013).

Table 11. White head \% of different rice genotypes as affected by sowing dates in 2011 and 2012 seasons.

\begin{tabular}{|l|c|c|c|c|c|c|c|c|}
\hline \multirow{2}{*}{\multicolumn{1}{c|}{$\begin{array}{c}\text { Genotypes } \\
\text { (G) }\end{array}$}} & \multicolumn{9}{|c|}{ Sowing dates (S) } \\
\cline { 2 - 9 } & $\begin{array}{c}\text { May } \\
\mathbf{1}^{\text {st }}\end{array}$ & $\begin{array}{c}\text { May } \\
\mathbf{1 5}^{\text {th }}\end{array}$ & $\begin{array}{c}\text { May } \\
\mathbf{3 0}^{\text {th }}\end{array}$ & $\mathbf{M}$ & $\begin{array}{c}\text { May } \\
\mathbf{1}^{\text {st }}\end{array}$ & $\begin{array}{c}\text { May } \\
\mathbf{1 5}^{\text {th }}\end{array}$ & $\begin{array}{c}\text { May } \\
\mathbf{3 0}^{\text {th }}\end{array}$ & $\mathbf{M}$ \\
\hline Giza 177 & 7.17 & 1.66 & 3.70 & 4.18 & 8.67 & 3.16 & 5.20 & 5.68 \\
Giza 178 & 1.80 & 1.50 & 1.02 & 1.44 & 3.30 & 3.00 & 2.52 & 2.94 \\
Sakha 101 & 0.98 & 0.75 & 0.75 & 0.83 & 2.48 & 2.25 & 2.25 & 2.33 \\
Giza 182 & 1.96 & 6.80 & 3.65 & 4.14 & 3.46 & 8.30 & 5.15 & 5.64 \\
GZ 9057-6-1-3-2 & 4.88 & 10.63 & 2.31 & 5.94 & 6.38 & 12.13 & 3.81 & 7.44 \\
GZ 9577-4-1-1 & 4.48 & 2.32 & 1.17 & 2.66 & 5.98 & 3.82 & 2.67 & 4.16 \\
GZ 9523-2-1-1-1 & 4.26 & 5.38 & 0.75 & 3.46 & 5.76 & 6.88 & 2.25 & 4.96 \\
GZ 9461-4-2-3-1 & 1.78 & 3.00 & 1.00 & 1.93 & 3.28 & 4.50 & 2.50 & 3.43 \\
Egyptian Yasmin & 7.00 & 8.27 & 3.69 & 6.32 & 8.50 & 9.77 & 5.19 & 7.82 \\
SK2034 H1 & 8.55 & 4.07 & 3.45 & 5.36 & 10.05 & 5.57 & 4.95 & 6.86 \\
\hline Mean & 4.29 & 4.44 & 2.15 & & 5.79 & 5.94 & 3.65 & \\
\hline
\end{tabular}

Insects storage (Rhizopertha dominica):

For evaluate susceptibility of rice varieties to insect infestation in storage, Rhizopertha dominica were released on tested varieties. The results in (Table 12) showed that significant differences among the mean numbers of adult emergence of Rhizopertha dominica. The number of adult emergence ranged from 1.08 insect (Sakha101) to 8.25 insect (GZ9577-4-1-1) (low susceptibility varieties to insect infestation). Also, the number of adult 
emergence ranged from 13.08 insect with Giza182 to 17.58 insect with Giza177 as moderate susceptibility varieties to insect infestation). Also, the number of adult emergence ranged from 21.08 insect with Egyptian Yasmin to 22.58 insect with GZ 9057-6-1-3-2 as (high susceptibility varieties to insect infestation). There is no effect of cultivation time on susceptibility, except (Giza177) at (May $1^{\text {st }}$ ), number of adult emergence was increased to 28.75, 30.25 insect, (GZ 9057-6-1-3-2) and (Egyptian Yasmin) at (May 15 ${ }^{\text {th }}$ ) was increased to $34.75,36.25$ insect at 2011,2012 season, respectively.

Table 12. Mean numbers of adult emergence of Rhizopertha dominica in 2011 and 2012 seasons at differences sowing dates.

\begin{tabular}{|c|c|c|c|c|c|c|c|c|}
\hline \multirow{3}{*}{ Genotypes } & \multicolumn{8}{|c|}{ Mean numbers of adult emergence } \\
\hline & \multicolumn{4}{|c|}{2011 season } & \multicolumn{4}{|c|}{2012 season } \\
\hline & May $1^{\text {st }}$ & $\begin{array}{l}\text { May } \\
15^{\text {th }}\end{array}$ & $\begin{array}{c}\text { May } \\
30^{\text {th }}\end{array}$ & M & May $1^{\text {st }}$ & $\begin{array}{l}\text { May } \\
15^{\text {th }}\end{array}$ & $\begin{array}{c}\text { May } \\
30^{\text {th }}\end{array}$ & M \\
\hline Giza 177 & 28.75 & 5.75 & 13.75 & 16.08 & 30.25 & 7.25 & 15.25 & 17.58 \\
\hline Giza 178 & 5.75 & 3.75 & 1.75 & 3.75 & 7.25 & 5.25 & 3.25 & 5.25 \\
\hline Sakha 101 & 1.75 & 0.75 & 0.75 & 1.08 & 3.25 & 2.25 & 2.25 & 2.58 \\
\hline Giza 182 & 5.75 & 23.75 & 9.75 & 13.08 & 7.25 & 25.25 & 11.25 & 14.58 \\
\hline GZ 9057-6-1-3-2 & 17.75 & 34.75 & 10.75 & 21.08 & 19.25 & 36.25 & 12.25 & 22.58 \\
\hline GZ 9577-4-1-1 & 10.75 & 6.75 & 2.75 & 6.75 & 12.25 & 8.25 & 4.25 & 8.25 \\
\hline GZ 9523-2-1-1-1 & 16.75 & 25.75 & 0.75 & 14.42 & 18.25 & 27.25 & 2.25 & 15.92 \\
\hline GZ 9461-4-2-3-1 & 5.75 & 9.75 & 1.75 & 5.75 & 7.25 & 11.25 & 3.25 & 7.25 \\
\hline Egyptian Yasmin & 19.75 & 34.75 & 8.75 & 21.08 & 21.25 & 36.25 & 10.25 & 22.58 \\
\hline SK2034 H1 & 16.75 & 15.75 & 11.75 & 14.75 & 18.25 & 17.25 & 13.25 & 16.25 \\
\hline Mean & 12.95 & 16.15 & 6.25 & 11.78 & 14.45 & 17.65 & 7.75 & 13.28 \\
\hline
\end{tabular}

\section{Genetic parameters for yield character:}

Estimates of genotype variance, phenotypic and genotypic coefficient of variability percentages, heritability and genetic advance percentage for grain yield (t/ha) character in two years (2011 and 2012) are presented in Table (13). The ten rice genotypes showed a wide range of mean performance under different seasons. Mean squares for all traits of all genotypes were highly significant in different years. Thus, the selection for all traits among these cultivars would be effective to improve traits of all genotypes. Similar results were obtained by Han et al., (1995), Tang (1995), Veillet et al., (1996), Hammoud et al (2012) and El-Malky et al., (2013). The phenotypic coefficient of variability (PCV\%) was higher than genotypic coefficient variability (GCV\%) in different years in all genotypes, indicating that the most portion of PCV\% was more contributed by environmental conditions and cultural practices. Relatively, high genetic coefficient of variability was found to be higher for grain yield (t/ha), and gave 15.82 in season 2011 and 16.77 in season 2012, respectively indicating that this traits might be more genotypically predominant, and it would be possible to achieve further improvement in both traits. The genetic coefficient of variability refers to the additive and non additive genetic variance played an important role in inheritance of these traits. These results are in agreement with those of Han et al., (1995), Tang (1995), Veillet et al., (1996), Hammoud et al (2012) and El-Malky et al., (2013). 
Heritability and genetic advance under selection were computed and the obtained results are illustrated in Table (13). High estimates of heritability were found in this characters under investigation in different two years, which ascertains the presence of both additive and non additive genetic variance in the inheritance of most traits except panicle weight which ranged from $87.73 \%$ to $91.17 \%$. These traits were stable under different condition and culture practices. Therefore, it could be concluded that its selection procedures are successful in improving the most traits under examination. Some results were previously obtained Han et al., (1995), Tang (1995), Veillet et al., (1996), Hammoud et al., (2012) and El-Malky et al., (2013).

Genetic advance under selection which presented in (Table 13) showed the possible gain from selection when the most desirable $5 \%$ of the plants are selected. Relatively, moderate genetic gains were obtained for grain yield ( $\mathrm{t} / \mathrm{ha}$ ), which gave more than $20 \%$. Low genetic advance were found in remaining characters less than $10 \%$ under different years. Johnson et al (1955) revealed that heritability estimates along with genetic gain upon selection were more valuable than the former alone in predicting the effect of selection. On the other hand, Dixit et al. (1970) pointed out that high heritability is not always associated with high genetic gain, but in order to make effective selection, high heritability should be associated with high genetic gain. In this investigation, high genetic gain was found to be associated with high heritability estimates for gain. Consequently, selection for these traits should be effective and satisfactory for successful breeding purposes. Moderate estimates of both heritability and genetic advance were obtained for plant height and grain yield ( $t / h a)$. Therefore, selection for these traits in these two characters will be effective, but probably of less success than in the former characters. Low genetic gain was associated with low heritability values for the rest of the characters studied. Hence, selection for these traits would be of less effectiveness. Similar results were obtained by Han et al., (1995), Tang (1995), Veillet et al., (1996), Hammoud et al., (2012) and El-Malky et al.,(2013).

Table 13:Estimates of phenotypic (PCV) and genotypic coefficient of variability (GCV), heritability ( $\mathrm{H}$. bs) and expected genetic advance $(\Delta \mathrm{g} \%)$ for grain yield $(\mathrm{t} / \mathrm{ha})$ traits in 10 genotypes of rice.

\begin{tabular}{|l|c|c|}
\hline \multicolumn{1}{|c|}{ Genetic parameters } & \multicolumn{2}{c|}{ grain yield (t/ha) } \\
\cline { 2 - 3 } & $\mathbf{2 0 1 1}$ & $\mathbf{2 0 1 2}$ \\
\hline Mean & 7.558 & 7.426 \\
\hline Variance & $8.79^{\star \star}$ & $9.45^{\star *}$ \\
\hline M.S. Error & 0.19 & 0.15 \\
\hline GV & 1.43 & 1.55 \\
\hline PV & 1.63 & 1.70 \\
\hline GCV\% & 15.82 & 16.77 \\
\hline PCV\% & 16.89 & 17.56 \\
\hline $\mathrm{H} . \mathrm{bs}$ & 87.73 & 91.18 \\
\hline$\Delta \mathrm{g}$ & 2.31 & 2.45 \\
\hline$\Delta \mathrm{g} \%$ & 30.53 & 32.99 \\
\hline
\end{tabular}


Clustering of the varieties based on agronomic characters:

The characters used for this purpose in the present study were the same morphological agronomical quantitative characters. Normality was checked for all traits, which indicated that all traits had good approximations of normal distributions (Fahmi et al 2005 and El-Malky et al 2013). Clustering varieties, based on similarity of quantitative characters, produced two large groups (Fig.2). The first one included five rice genotypes Giza 178, Giza 182, GZ 9523-2-1-1-1, Egyptian Yasmin and SK2034 H1. These genotypes were Indica and Indica-Japonica types except Gz 9523-2-1-1-1 genotype and also simlar in filled grains character. While, the second group included Giza 177, Sakha 101, GZ 9057-6-1-3-2, GZ 9577-4-1-1 and GZ 9461-4-2-3-1 genotypes were Japonica types and similar in duration and grain yield characters.

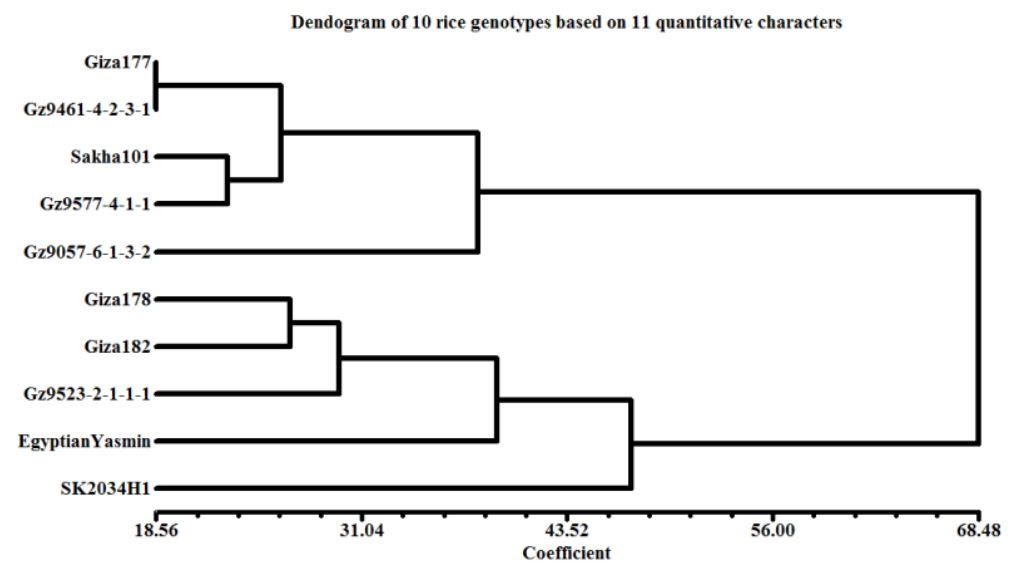

Fig. 2: Cluster diagram for ten rice cultivars classified by 11 morphological quantitative characters.

\section{CONCLUSION}

It could be concluded that there is a significant effect of sowing dates on the yield, yield components and days taken to complete maturity of grain rice genotypes. Sowing on first May maximized yield of rice genotypes. All the rice genotypes under studies were found to be photoperiod sensitive. For white head \%, the japonica genotypes were more resistant to stem borer this du to that Japonica type has more silica content than Indica type as well as, the high level of silica seemed to interface with feeding and boring of the rice stem borer larvae and could cause defacing of the mandibles.

\section{REFERENCE}

Akhter M.; M. Ahmad and M. Ramzan (2007). Effect of photoperiod sensitivity on yield and other economic traits of new strains of basmati rice (Oryza sativa L.). The J. Anim. Plant Sci. 17(3-4): 79-82.

Akram, H. M.; A. Ali; M. A. Nadeem and S. Iqbal. (2007). Yield and yield components of ricevarieties as affected by transplanting dates. J. Agric. Res., 45(2): 105-111. 
Anonymous(2009). Food and Agriculture Organization of the United Nations. (2009): The state of food security in the world., p. 1-30.

Ashrafuzzaman, M.; M.R. Islam; M.R. Ismail; S.M. Shahidullah and M.M. Hanafi, (2009). Evaluation of six aromatic rice varieties for yield and yield contributing characters. Int. J. Agric. Biol., 11: 616-620.

Badawy,A.I. and Naser Ibn Doraeham Y.(1991). Stored grain and products, pests and their control, King Soud Unviv., Soudia Arabia (In Arabic).

Bahraman, N.; J. L. Gouis; D. Hariri; L. Guilbaud and L. Jestin. (1999). Genetic diversity of old French six-rowed winter barley cultivars assessed with molecular, biochemical and morphological markers and its relation to BaMMV resistance. Heredity, $83: 568-574$.

Bleih, S.; S.B. Desgun and R. Ramachandran (1991). Comparative observations on the pest and disense incidence and yield losses of japonica, Indica and Indica x Japonica rice Tropical pest Management. 37 (3): 290-295

Bruns, H.A.and H.K. Abbas (2006). Planting date effects on Bt and NonBtcorn in the mid-south USA. Agron. J., 98: 100-106.

Campbell, A.and R.N. Sinha (1976). Damage of wheat by feeding of some stored product beetles. Journal of Economic Entomology 69, 11-13.

Chen. J. L.; F. J. Lu; J. P. Zhou; X . Peng; X. Z. Lu and Y. X. Xu (2003). Effect of sowing and transplanting date on development and growth of a Japonica hybrid rice variety, Changyou 1. Jiangsu Agricultural Sciences, (5):29-30.

Cooper, N.T.W.; T.J. Siebenmorgen; P.A. Counce and J.F. Meullenet (2006). Explaining rice milling quality variation using a historicalweather data analysis. Cereal Chem83:447-450.

Dawadi, K. P. and N. K. Chaudhary. (2013). Effect of sowing dates and varieties on yield and yield attributes of direct seeded rice in Chitwan, Nepal. Int. J. of Agric. Sci. Res., 2(4): 095-102.

Dingkhun, M. and F. Asch. (1999). Phenological responses of Oryza sativa, $O$. glaberrima and inter-specific rice varieties on a toposquence in West Africa. Euphytica, 110: 109-126.

Dixit, P.K.; P.D. Saxena and L. K. Bhatia (1970). Estimation of genotypic variability of some quantitative characters in groundnut. Indian J. Agric. Sci., 40: 197-201

Djamin, A. and M.D. Pathak (1967). Role of silica in resistance to asistic rice borer, Chilo suppresszlis (Walker), in rice varieties. J. Econ. Entomol., 60(2): 347-351.

Duncan, D.B. (1955). Multiple Range and Multiple F. Test.Biometrics.11:1-42.

El-Malky, M. M. (2004). Genetic studies on blast disease resistance in rice (Oryza sativa L.). Ph.D. Thesis, Fac. of Agric. Menofiya Univ.

El-Malky, M.M.; M.M. El-Habashy; S.A.A. Hammoud and M.R. Sreif (2013). Genetic studies of some rice varieties for rice stem borer (Chilo agamemnon Bles.) and agronomic characters under Egyptian condition. Egypt. J. Plant breed 17 (2): 196-212. 
Fahmi, A.I.; I.R. Aidy; H.H. Nagaty and M.M. El-Malky (2005). Genetic diversity of short-Grwoth Duration Germplasm of Rice (Oryza sativa L.) as Reveald by RAPD and Microsatellite Markers. Egypt.J. Genet. Cytol., 34:29-49

Ganajaxi, H.D.Mohankumar; Y. Hegde and V.V. Angadi. (2001). Effect of planting dates and $\mathrm{N}$ Levels on the grain yield of aromatic rice varieties under rainfed conditions. Karnataka J. Agric. Sci., Univ. Agric. Sci. Dharwad, India..14(3):758-759.

Gomez K. and A. Gomez (1984). Statistical Procedures of Agricultural Research. John Wiley and Sons. Inc., New York, U.S.A.

Gundu Rao, H.R. and D.A. Wilbur (1957). Loss of wheat weight from feeding of lesser grain borer. Journal of the Kansas Entomological Society 45:238-241.

Hammoud, S.A.A.; S.E.M. Sedeek; I.O.A. Rewaniy and R.A. El-Namaky (2012). Genetic behavior of some agronomic traits, blast disease and stem borer resistance in two Levels. J. agric. Res., Kafr El-Sheikh. Univ. 38(1): 83-105.

Han, Q.L.; P. Zhuang; Z.H. Tang; Q.F. Han; P.J. Zhuang and Z.H. Tang (1995). Estimation of realized heritability of resistance to penetration rice stem borrer Chilo suppressalis. Acta. Entomology. Academia Siinca, 38 (4): 402-406.

Johnson, H.W.; H.F. Robinson and H.R. Constock (1955). Estimation of genetic and environmental variation in soybeans. Agron. J., 47:313318.

Krell, R. K; L. P. Pedigo; M. E. Rice; M. E. Westgate; J. H. Hill (2005). Using planting date to manage bean pod mottle virus in soybean. Crop Protection, 24: 909-914.

Maiti, P.K., and S.N. Sen. (2003). Crop Mangement for Improving Boro Rice Productivity in West Bengal. Boro Rice. Ed. R.K. Singh, M. Hossain and R. Thakur, Intl. Rice Res. Inst., India Office, Pusa Campus, New Delhi-i 10012, India. pp. 167-173.

Metwally, T. F.; M. M. El-Malky; A. A. Glelah and A. S. Gharieb (2012). Performance of elite aromatic rice varieties under different sowing dates under Egyptian condition. J. Plant production Univ., 3 (2): 311333.

Moldenhauer, K.A.K.; J.H. Gibbons and K.S. McKenzie (2004). Rice varieties. In: Champagne, E.T. (Ed.), Rice Chemistry and Technology, third ed. The American Association of Cereal Chemists, Inc., St. Paul,MN, USA pp. 49-75.

Munda, G.C.; P.B. Chaudhri and C.S. Patel. (1994). Variety, date of transplanting and space on high altitude rice. Indian J. Hill Farming, $7(1):$ : 96-98.

Nazir, M.S. (1994). Crop Production. (Ed.): E. Bashir and R. Bantel. National Book Foundation, Islamabad. pp. 252.

Pandey N.; Verma A.K. and R.S. Tripathi (2001). Effect of planting time and nitrogen on tillering pattern, dry matter accumulation and grain yield of hybrid rice. Indian J. Agric. Sci., 71(5): 337-338. 
Pathak, M.D. (1967). Insect pests of rice at the International Rice Research Institute. Los Banos, Laguna, Philippines, 68pp

Rashid, M.; A.A. Cheema; A. Ashraf; Z. Qamar and Z. Mahmood (2003). Development of basmati rice varieties through the use of induced mutations and related techniques. Pak. J. Bot., 35(3):811-818.

Rohlf, F.J. (2000). NTSYS-PC manual Exeter Software, Setauket, New York.

RRTC (2006). National Rice Research Program : Final result of 2005 growing season. Sakha, Egypt.

Safdar, M. E., A. Ali, S. Muhammad, G Sarwar and T. H. Awan. (2008). Effect of transplanting dates on paddy yield of fine grain rice genotypes. Pak. J. Bot., 40(6): 2403-2411, 2008.

Sha X. and S.D. Linscombe (2005). Planting date is critical for maximizing rice yield and milling quality. Louisiana Agric., 48(3): 6-8.

Souza, E. and M. E. Sorrells (1991). Relationships among 70 North American Oat germplasms: 1. Cluster analysis using quantitative characters. Crop Sci. 31: 599-605.

Subramanyam,B., and D.W. Hagstrum (1995). Resistance meusurment and management. In: Subramanyam, B., Hagstrum D.W. (Eds), Integrated Management of Insects in Stored Products. Marcel dekker Inc. New York pp. 331-398. Champ, B.R.), 2,pp.650-659.Canberra, Australia.

Tang, Z.H. (1995). Estimation of realized heritability of resistance to penetration in rice stem borer Chilo suppressalies. Entomology. Science. 38 (1):233-235.

Tantawi, A.M., F.E. Abdallah and A.M. Soliman (1985). Losses in rice yield due to the rice stem borer, Chilo agamennon Bles. Proc. Gth Arab Pesticide Conf. Tanta Univ., 2: 183-189.

Veillet, S.; M.C. Filippi and A. Gallais (1996). Combined genetic analysis of partial blast resistance in an upland rice population and recurrent selection for line and hybrid values. Appli. Genet. 92: 644-653.

Wassmann, R.; S.V.K. Jagadish; S. Heuer; A. Ismail; E. Redona; R. Serraj; R.K. Singh; G. Howell; H. Pathak; K. Sumfleth (2009). Climate change affecting rice production: The physiological and agronomic basis for possible adaptation strategies. In: D. L. Sparks (ed.) Advances in Agron. Vol 101. Burlington, Academic Press, pp. 59-122.

Yoshida, S. (1981). Fundamentals of rice crop science. International Rice Research Institute, Los Banos, Laguna, Pilippines, pp. 94-110.

Zheng. X.; J.G. Wu; X.Y. Lou; H.M. Xu and C.H. Shi (2008). The QTL analysis on maternal and endosperm genome and their environmental interactions for characters of cooking quality in rice (Oryza sativaL.). Theor Appl Genet116:335-342. 
السـلوك الـور اثي لصـفات المحصـول وجـودة الحبـوب والإصـابة بثاقبـة سـاق الأرز

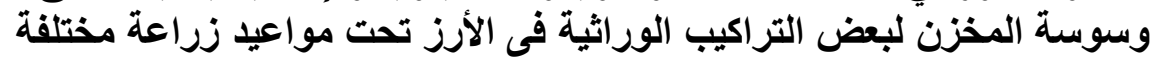

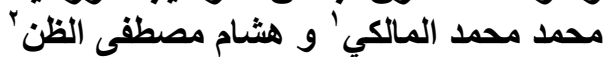

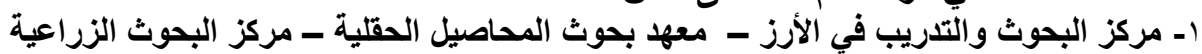

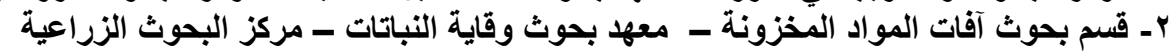

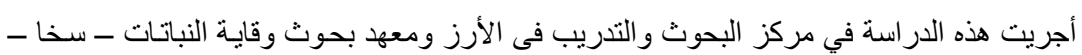

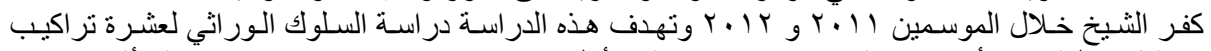

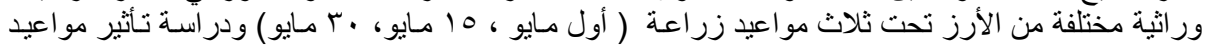

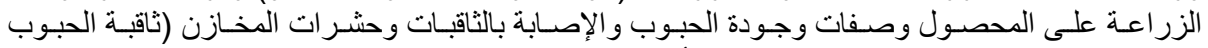

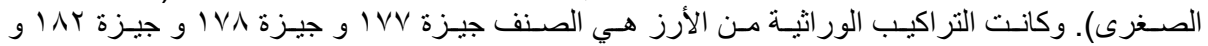
وكجن و وهجين مصري واحد. و و يكن تلخيص أهم النتائج فيما يلي:

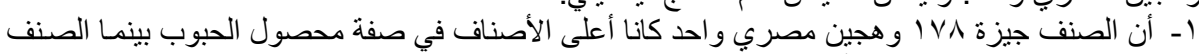

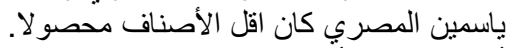

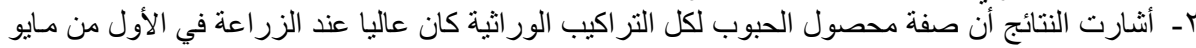

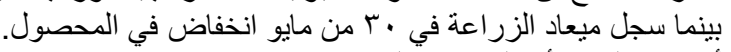

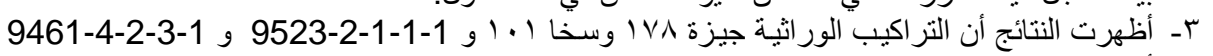

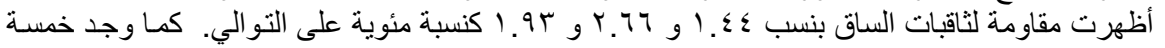

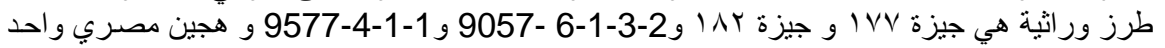

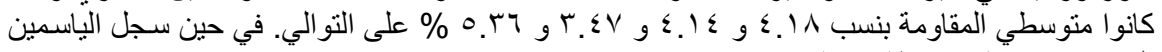

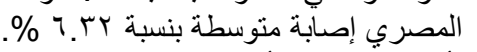

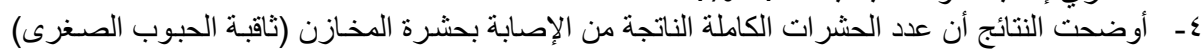

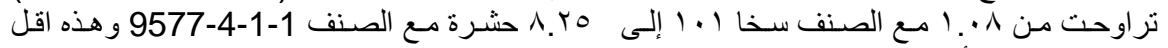

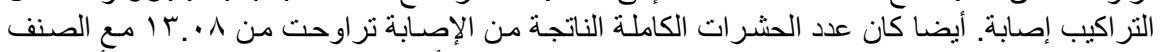

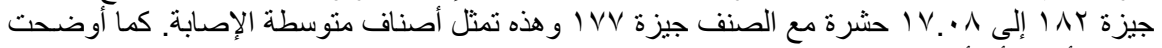

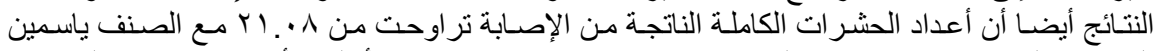

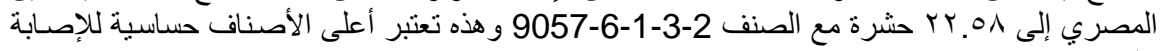

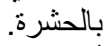

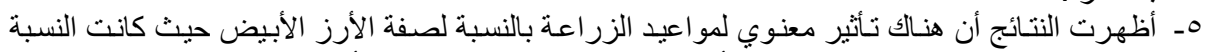

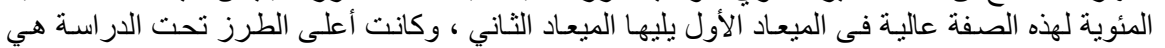

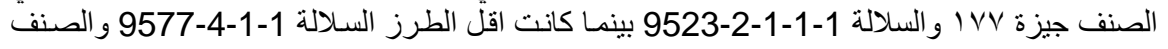

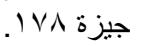

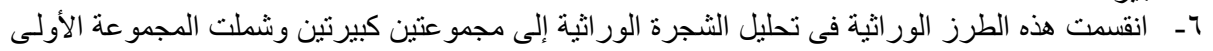

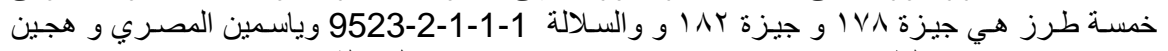

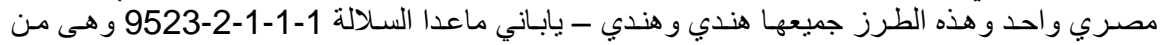

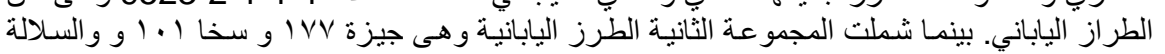
وصنا وصفة محصول الحبوب. 
El-Malky, M.M. and H.M. El-Zun

El-Malky, M.M. and H.M. El-Zun El-Malky, M.M. and H.M. El-Zun El-Malky, M.M. and H.M. El-Zun El-Malky, M.M. and H.M. El-Zun El-Malky, M.M. and H.M. El-Zun El-Malky, M.M. and H.M. El-Zun El-Malky, M.M. and H.M. El-Zun El-Malky, M.M. and H.M. El-Zun El-Malky, M.M. and H.M. El-Zun El-Malky, M.M. and H.M. El-Zun El-Malky, M.M. and H.M. El-Zun El-Malky, M.M. and H.M. El-Zun El-Malky, M.M. and H.M. El-Zun El-Malky, M.M. and H.M. El-Zun El-Malky, M.M. and H.M. El-Zun El-Malky, M.M. and H.M. El-Zun El-Malky, M.M. and H.M. El-Zun El-Malky, M.M. and H.M. El-Zun El-Malky, M.M. and H.M. El-Zun El-Malky, M.M. and H.M. El-Zun El-Malky, M.M. and H.M. El-Zun El-Malky, M.M. and H.M. El-Zun El-Malky, M.M. and H.M. El-Zun El-Malky, M.M. and H.M. El-Zun El-Malky, M.M. and H.M. El-Zun El-Malky, M.M. and H.M. El-Zun El-Malky, M.M. and H.M. El-Zun El-Malky, M.M. and H.M. El-Zun El-Malky, M.M. and H.M. El-Zun El-Malky, M.M. and H.M. El-Zun El-Malky, M.M. and H.M. El-Zun El-Malky, M.M. and H.M. El-Zun El-Malky, M.M. and H.M. El-Zun El-Malky, M.M. and H.M. El-Zun El-Malky, M.M. and H.M. El-Zun El-Malky, M.M. and H.M. El-Zun El-Malky, M.M. and H.M. El-Zun El-Malky, M.M. and H.M. El-Zun El-Malky, M.M. and H.M. El-Zun 